\title{
NOTES
}

\section{FOCUSING ON DEMAND SIDE MANAGEMENT IN THE FUTURE OF THE ELECTRIC GRID}

\section{Steven D. Czajkowski}

\section{INTRODUCTION}

The widespread blackout that occurred on August 14, 2003 ("the blackout") exposed the weaknesses of the current electric transmission grid structure, and underscored the need for improvements to the transmission grid in the United States. The outage knocked out power to approximately fifty million people in Ohio, Michigan, Pennsylvania, New York, Vermont, Massachusetts, Connecticut, New Jersey and the Canadian province of Ontario. ${ }^{1}$ The total cost in the United States was estimated to be between $\$ 4$ and $\$ 10$ billion. $^{2}$

Although it is difficult to pinpoint a single cause of the outage given the many processes and functions intertwined within the transmission grid system, the U.S.-Canada Power System Outage Task Force ${ }^{3}$ summarized the main

\footnotetext{
* University of Pittsburgh, School of Law, J.D. 2010 cum laude. The author would like to thank all the journal staff that helped in the development of this article. In addition he would like to thank his family and friends for their continuous love and support.

1. U.S.-Canada Power System Outage Task Force, Final Report on the August 14, 2003 Blackout in the United States and Canada: Causes and Recommendations 1 (2004), available at https://reports.energy.gov/BlackoutFinal-Web.pdf.

2. Id.

3. The Task Force was created in 2003 by then U.S. President George W. Bush and then Canadian
} 
causes of the blackout into four general categories in its report on the actions and events that took place that day:

1. FirstEnergy ("FE"), the electric provider for much of Northern Ohio and the reliability coordinator ${ }^{4}$ for the transmission system in that portion of the country, failed to assess and understand the inadequacies of FE's power system and FE did not operate its system within the proper voltage boundaries.

2. FE did not recognize or understand the deterioration of its system.

3. FE did not properly manage tree growth within transmission line rights-of-way.

4. The interconnected power grid's reliability organizations failed to provide adequate real-time support. ${ }^{5}$

The transmission grid is "the interconnected group of power lines and associated equipment for moving electric energy at high voltage between points of supply and points at which it is delivered to other electric systems or transformed to a lower voltage for delivery to customers." "The current electric transmission grid is made up of 211,000 miles of high voltage power lines that serve approximately 334 million consumers. ${ }^{7}$

The blackout demonstrated the serious problems that the size, complexity, and constant use of the U.S. transmission grid can create. And the situation is only expected to get worse. According to an estimate by the Energy Information Administration ("EIA"), ${ }^{8}$ energy consumption around the world

Prime Minister Jean Chretien to investigate the causes of the blackout and to find ways to reduce the possibility of future outages. Id.

4. "The Reliability Coordinator is responsible for the real-time operating reliability of its Reliability Coordinator Area, and coordinates closely with neighboring areas. It has the authority to prevent or mitigate emergency operating situations in real-time and in next-day analysis." Any entity that operates transmission facilities must be under the purview of a reliability coordinator. North American Electric Reliability Corporation, About NERC: Understanding the Grid, Reliability Terminology, http://www.nerc.com/ page.php?cid=1|15|122 (last visited Mar. 30, 2010).

5. See U.S.-CAnada Outage Task Force, supra note 1, at 58.

6. Department of Energy, Frequently Asked Questions, http://www.oe.energy.gov/information center/faq.htm\#sys3 (last visited Mar. 12, 2010). High voltage typically refers to voltages above $100 \mathrm{kV}$. See Department of Energy, National Transmission Grid Study 5-7 (2002), http://www.pi .energy.gov/documents/TransmissionGrid.pdf.

7. North American Electric Reliability Corporation, supra note 4.

8. "The U.S. Energy Information Administration collects, analyzes, and disseminates independent and impartial energy information to promote sound policymaking, efficient markets, and public understanding of energy and its interaction with the economy and the environment." See U.S. Energy Information Administration, About EIA, http://tonto.eia.doe.gov/abouteia/ (last visited Apr. 4, 2010). 
to increase fifty percent by 2030; electricity is expected to remain the fastestgrowing form of end-use energy ${ }^{9}$ worldwide through the same period..$^{10}$

Because of the ongoing demand for electricity and questions of reliability with electricity delivery, there is increasing interest in funding improvements to transmission grid infrastructure. Along with this, increasing environmental and energy security concerns over the use of fossil fuels have focused attention on the use of renewable energy to supply the growing demand. ${ }^{11}$

At first glance, the increased use of renewable energy sources seems like an obvious solution to both environmental and supply issues. However, the use of renewable sources introduces additional challenges beyond just the complexities inherent in operating the existing transmission grid. Additional infrastructure will be necessary to transport electricity from a renewable source to an end use customer because renewable sources are typically not located as conveniently as traditional generation sources, such as coal or natural gas. ${ }^{12}$ With longer power lines, less of the power generated is delivered to where it is used. Additionally, extending power lines to the location of renewable sources can be cost-prohibitive. ${ }^{13}$

In order to continue to provide electricity to the public, the transmission grid will inevitably need to be expanded. Despite this, expansion should only be carried out after the appropriate steps are taken to ensure that electricity is being used in the most efficient manner. The industry term describing this process is Demand Side Management ("DSM"). ${ }^{14}$ DSM involves actions by utilities to alter consumers' usage patterns in order to conserve electricity. ${ }^{15}$ By implementing DSM programs, electric utilities may be required to forego profits based on lower sales of electricity but this can be made up through program incentives or the avoided costs of not having to build new generating

9. An end user of energy is defined by the EIA to be "a firm or individual that purchases products for its own consumption and not for resale (i.e., an ultimate consumer)." ENERGY INFORMATION ADMINISTRATIOn, GLOSSARY, http://www.eia.doe.gov/glossary/glossary_e.htm(last visited Mar. 13, 2010).

10. Energy Information Administration, International Energy Outlook 2008 (2008), http://www.eia.doe.gov/oiaf/ieo/electricity.html (last visited Jan. 15, 2009).

11. Alborz Nowamooz, Inadequacy of Transmission Lines: A Major Barrier to the Development of Renewable Energy, 3 Envtl. \& Energy L. \& Pol'y J. 176, 176 (2008).

12. See David R. Baker, Getting Renewable Power to the People, San Francisco Chronicle, Dec. 28, 2008, http://www.sfgate.com/cgi-bin/article.cgi?f=/c/a/2008/12/28/MN5C14VFGS.DTL.

13. Typical problems include eminent domain in construction, landscape impacts, and maintenance of power lines.

14. Jeff Guldner \& Meghan Grabel, Dealing with Change: The Long-Term Challenge for the Electric Industry, 23 NAT. Resources \& ENV'T 3, 3 (2008).

15. Joseph Eto, The Past, Present, and Future of U.S. Utility Demand-Side Management Programs 1 (1996), available at http://eande.lbl.gov/EA/EMS/reports/39931.pdf. 
facilities. ${ }^{16}$ It is also possible for consumers to receive a direct economic benefit from lower consumption while having the ability to directly control their energy usage..$^{17}$

This note argues that DSM should take priority over new transmission line construction and renewable energy sources in future energy legislation and regulation. Section II looks at the beginning of the electric grid and how regulation has led to the grid we have today. Section III discusses the problems with the operation of the current grid and presents the associated drawbacks to new power line construction and using renewable sources for generating electricity. Section IV provides an in depth look at DSM and what steps the federal government can take to further its application. This note concludes with a current example of the successful use of a DSM program.

\section{The Evolution and Regulation of the Transmission Grid}

\section{A. The Development of Transmission Systems}

Electricity was first used for industrial purposes in the 19th century. At that time, electricity generators were placed close to the machines that used electricity, eliminating transmission concerns. ${ }^{18}$ In 1882, Thomas Edison developed the first transmission grid in New York City, but, because the delivery method, direct current, was inefficient. Only fifty-two people living in the one square mile surrounding the generating facility were served. ${ }^{19}$

By the late 1800s, Edison's former co-workers found that alternating current was a more efficient way to transport electricity and therefore allowed electricity to be transmitted over greater distances. ${ }^{20}$ One of the first applications of alternating current involved a hydroelectric generating station located at Niagara Falls that feed electricity to Buffalo, New York, located twenty miles away. ${ }^{21}$

16. Scott F. Bertschi, Integrated Resource Planning and Demand-Side Management in Electric Utility Regulation: Public Panacea or a Waste of Energy?, 43 EMORY L.J. 815, 831 (1994).

17. Id. at 826 .

18. National Council on Electric Policy, Electricity Transmission a Primer 2 (2004), http://www.ncouncil.org/Documents/primer.pdf.

19. Id; see also Oracle Education Foundation, The Shocking Truth About Electricity, The History of Electricity, http://library.thinkquest.org/6064/history.html (last visited Apr. 4, 2010).

20. National Council on Electric Policy, supra note 18.

21. Id. 


\section{B. The Emergence of the Electricity Market and the Need for Regulation}

The utilization of alternating current greatly expanded the market for electricity. By the early 1900 s, the electricity market had become so vast that most state governments used the power of their regulatory commissions over railroads to regulate electricity markets. ${ }^{22}$

As the electricity market grew, consolidation of the industry took place. ${ }^{23}$ By 1932 approximately three quarters of the electricity market was held by eight public holding companies. These companies were not under state commission jurisdiction because the companies crossed state lines. Therefore, federal intervention was necessary for regulation to be effective. ${ }^{24}$

One of the first pieces of legislation to regulate the electric industry was the Public Utility Holding Company Act ("PUHCA"), passed in 1935. ${ }^{25}$ PUHCA facilitated state regulation by "free[ing] utility operating companies from the absentee control of holding companies ...." ${ }^{26}$ This legislation also protected both consumers and investors against potentially questionable business practices by unregulated utility holding companies. ${ }^{27}$

Another important piece of legislation in 1935 was an amendment to the Federal Water Power Act of 1920. This Act originally created the Federal Power Commission ("FPC"), ${ }^{28}$ which is now known as the Federal Energy Regulatory Commission ("FERC"). The 1935 amendment gave the FPC, and thereafter FERC, primary regulatory authority over the interstate sale and transmission of electricity. ${ }^{29}$

The next major piece of legislation regulating the electricity industry, the Public Utility Regulatory Policies Act of 1978 ("PURPA") was passed in 1978. PURPA forced the utility companies to purchase power from certain non-utility generators, or Independent Power Producers ("IPP"). ${ }^{30}$ Before

22. Id. at 3 .

23. $I d$.

24. $I d$.

25. $I d$.

26. Nidhi Thakar, The Urge to Merge: A Look at the Repeal of the Public Utility Holding Company Act of 1935, 12 Lewis \& Clark L. ReV. 903, 911 (2008).

27. Id. at 904 .

28. Clyde L. Seavey, Functions of the Federal Power Commission, 201 Am. ACAD. OF Pol. \& Soc. SCI. 73, 73 (1939). In 1977, Congress replaced the FPC with the Federal Energy Regulatory Commission ("FERC"), which undertook the responsibilities of the FPC. Federal Energy Regulatory Commission, Students' Corner, What is FERC?, http://www.ferc.gov/students/whatisferc/history.htm (last visited Apr. 4, 2010).

29. Id.

30. James D. Elliott, Electric Utility Regulation Reform in New York: Economic Competitiveness 
PURPA, the activities of IPPs were restricted in two significant ways: 1) an IPP could not sell electricity directly to retail customers if it did not have a state retail franchise and 2) an IPP could not effectively sell power generation on the wholesale market because local utilities could simply decline to purchase the electricity. ${ }^{31}$ PURPA's requirements related to the use of renewable energy ${ }^{32}$ and effectively promoted the use of such sources. ${ }^{33}$

The Energy Policy Act of 1992 ("EPAct 1992") further opened the market for electric generation. The EPAct 1992 removed many restrictions on IPPs put in place by the PUHCA. ${ }^{34}$ It also sought to increase competition in the wholesale electricity market as a means to increase energy efficiency and conservation by utility companies. One of the main ways was by requiring state utility commissions to consider implementing DSM programs. ${ }^{35}$

In 1996 and 1999, FERC supplemented the provisions of EPAct 1992 with Orders No. 888 and 2000, which further opened national electricity markets by mandating that utilities provide open and non-discriminatory access to the transmission grid for IPPs. ${ }^{36}$ These regulations created the Independent System Operator ("ISO") ${ }^{37}$ and the Regional Transmission Organization ("RTO"). ${ }^{38}$ These Orders created a wholesale market where a separate entity, the ISO or RTO, took over control of the operation of the transmission grid in a given state or states from the utility that owned the power lines. ${ }^{39}$

at the Expense of the Environment, 13 PACE EnvtL. L. Rev. 281, 291 (1995).

31. Jeffrey D. Watkiss \& Douglas W. Smith, The Energy Policy Act of 1992-A Watershed for Competition in the Wholesale Power Market, 10 YALE J. on REg. 447, 453 (1993).

32. Id.

33. Union of Concerned Scientists, Public Utility Regulatory Policy Act (PURPA), http:// www.ucsusa.org/clean_energy/solutions/big_picture_solutions/public-utility-regulatory.html (last visited Mar. 12, 2010).

34. Id.

35. Elliott, supra note 30, at 293-94.

36. John S. Moot, Economic Theories of Regulation and Electricity Restructuring, 25 ENERGY L.J. 273, 274-75 (2004).

37. An Independent System Operator is defined as "[a]n independent, Federally regulated entity established to coordinate regional transmission in a non-discriminatory manner and ensure the safety and reliability of the electric system." Federal Energy Regulatory Commission, Glossary, http://www.ferc.gov/ help/glossary.asp (last visited Apr. 4, 2010).

38. A Regional Transmission Organization functions similarly to an ISO, except it covers a larger area. See Federal Energy Regulatory Commission, Regional Transmission Organizations (RTO)/ Independent System Operators (ISO), http://www.ferc.gov/industries/electric/indus-act/rto.asp (last visited Apr. 4, 2010)

39. See Federal Energy Regulatory Commission, Industries RTO/ISO, http://www.ferc.gov/ industries/electric/indus-act/rto.asp (last visited Jan. 15, 2009). 
Where previously utility companies owned and operated both the generation and transmission facilities, legislation and FERC regulations in the 1990s allowed more IPPs to sell electricity into the wholesale market. This form of deregulation was further enhanced by the RTOs and ISOs that run wholesale markets where the price of electricity is determined on a competitive basis instead of the cost of production. ${ }^{40}$ From 1996 to 2000, twenty-four states attempted to follow this deregulation model by passing legislation, called "retail access policies," that allowed retail customers to choose their generation supplier. ${ }^{41}$ However, this retail access movement ended rather quickly as competition at the retail supply level did not develop. ${ }^{42}$ Since 2000 , no new states have adopted these policies and only sixteen still have retail access policies in place. ${ }^{43}$

In the aftermath of the 2003 blackout, the Environmental Policy Act of 2005 ("EPAct 2005") was passed as a comprehensive energy policy for the country. The EPAct 2005" authorized the U.S. Secretary of Energy to designate areas of the transmission grid as "National Interest Electric Transmission Corridors" ("NIETCs"). ${ }^{44}$ This gives power to FERC to bypass many of the state authorities when it comes to choosing a site for transmission lines in these areas where capacity is constrained. ${ }^{45}$ This legislation appears to be a major step in addressing investment in the transmission grid, and it also grants FERC authority to promote the use of DSM and remove barriers to its application. ${ }^{46}$

40. The American Public Power Association, Fact Sheet-Wholesale Electricity MARKETS 1 (2009), http://www.appanet.org/files/PDFs/23\%20Wholesale\%20Markets.pdf.

41. Moot, supra note 36, at 286.

42. The American Public Power Association, supra note 40, at 2.

43. Moot, supra note 36, at 286.

44. Mark A. de Figueiredo, A Regulatory Framework for Investments in Electricity Transmission Infrastructure, 26 VA. EnVTL. L.J. 446, 446 (2008) (citing the Energy Policy Act of 2005, Pub. L. No. $109-58, \S 1221,119$ Stat. 594, 946 (2005)). NIETCs are determined based on the geographic location of customers that are burdened by congestion in the transmission grid, or the customers that are "downstream of the limiting transmission constraints." This is done in conjunction with identifying "areas with substantial amounts of existing underutilized generation capacity as well as areas with potential for substantial development of renewable generation." U.S. Department of Energy, National Electric Transmission Corridor Report and the Ordered National Corridor Designations, Frequently Asked Questions 2-3 (2007), available at http://nietc.anl.gov/documents/docs/FAQs_re_National_Corridors 10_02_07.pdf.

45. $I d$.

46. Jon Wellinghoff \& David L. Morenoff, Recognizing the Importance of Demand Response: The Second Half of the Wholesale Electric Market Equation, 28 ENERGY L.J. 389, 396 (2007). 


\section{Problems with the Current Grid}

With the increasing demand for electricity, the grid is put under more stress every year due to the quantity of electricity being transported. While electricity is currently provided with a reasonable amount of reliability, the Department of Energy ("DOE") has made it clear that major investments are needed to ensure that reliability is maintained and that the level of service the U.S. economy requires is met. ${ }^{47}$ The current grid suffers from two main problems: capacity limitations and growing public resentment towards using fossil fuels for electricity generation.

\section{A. Capacity}

Open access to the transmission grid has led to many new additions of non-utility generation ${ }^{48}$ nationwide. This increase in electricity generation exposed many of the capacity weaknesses of the system. ${ }^{49}$ These weaknesses are the result the localized nature of the original transmission grid and the lack of investment in the grid as demand has expanded and increased.

\section{Original Construction}

Because of the heavily regulated market in place when the transmission grid first emerged, utilities directed their expenditures to reliability, not economic competitiveness. ${ }^{50}$ As the population spread and demand for electricity increased, utilities had to decide how to effectively fund this growth. Instead of investing in new generating facilities as backups for existing facilities, utilities created ties with their neighbors. ${ }^{51}$ Utilities served their predefined local area, which limited the transmission distances. Because

47. See Department of Energy, supra note 6.

48. Non-utility generation refers to "[a] corporation, person, agency, authority or other legal entity or instrumentality that owns electric generating capacity and is not an electric utility." PPL Newsroom Glossary, http://www1.pplweb.com/MediaRelations $/ \mathrm{mrl} / \mathrm{mr}$ _glossary.show_term?p_id=129\&p_from_ multiple=TRUE (last visited Mar. 29, 2010).

49. Eric J. Lerner, What's Wrong with the Electric Grid? , http://www.aip.org/tip/INPHFA/vol-9/iss5/p8.html (last visited Mar. 12, 2010).

50. Peter Fox-Penner, Rethinking the Grid: Avoiding More Blackouts and Modernizing the Power Grid Will Be Harder Than You Think, 18 Electricity J. 28, 29 (2005).

51. Id. 
they used their own generators and transmission lines, electricity transmission was conducted with predictable results. ${ }^{52}$

However, in the current deregulated transmission market, electricity is not transmitted along the same paths as it once was. ${ }^{53}$ What was once an emergency connection between adjacent utilities to ensure reliability may now be the major nexus between cheaply generated electricity in the Midwest and high-energy demands in the East Coast. ${ }^{54}$ These connecting lines are bottlenecks to the flow of electricity because they were not designed to carry the necessary amount of electricity.

These transmission congestion problems have not gone unnoticed. The DOE has used the authority granted by the EPAct 2005 to designate two regions as NIETCs, the Southwest and the Mid-Atlantic. ${ }^{55}$ The designation allows FERC to bypass much of the approval process of the states within these areas. ${ }^{56}$ However, it does not allow FERC to issue authority for the construction of facilities in the first instance, this is still left up to state commissions and the utilities. ${ }^{57}$

\section{Investment}

The transmission grid must be able to handle transmitting electricity from remote areas to areas of demand as governing bodies become concerned with the environmental hazards and health risks of generating electricity in populated areas. Despite the increase in new generation sources, the rate of investment in the overall transmission grid has decreased. ${ }^{58}$ If current trends hold, electricity generation will increase by thirty percent over the next ten years, while transmission lines will only increase five percent. ${ }^{59}$

52. Id. at 30 .

53. Id. at $30-31$.

54. Id.

55. The Southwest area consists of parts of California and Arizona, while the Mid-Atlantic area is made up of counties within Pennsylvania, Ohio, West Virginia, Virginia, New York, Maryland, New Jersey, Delaware, and the District of Columbia. Department of Energy, DOE Designates Southwest Area and MidAtlantic Area National Interest Electric Transmission Corridors, Oct. 2, 2007, http://nietc.anl.gov/ documents/docs/NIETC Designation_News_Release.pdf.

56. See National Electric Transmission Corridor Report and the Ordered National Corridor Designations, supra note 44 , at $1-2$.

57. FERC can issue the authority to construct transmission facilities only if certain conditions are met. See id.

58. Fox-Penner, supra note 50, at 28 .

59. Id. 


\section{Concerns Over Building Power Lines to Increase Capacity}

The federal government has determined that the solution to capacity constraints within the Mid-Atlantic and Southwest areas is to build more power lines. ${ }^{60}$ Electric utilities in Pennsylvania, New York, and other eastern states are able to achieve a high rate of return on grid projects built within NIETCs, sometimes in excess of twelve percent. ${ }^{61}$ This demonstrates that building more transmission lines is the federally supported solution to congestion problems. While the government has embraced this solution, it is not without its drawbacks.

\section{a. Environmental Drawbacks}

Many environmentalists protest the construction of power lines due to the associated impacts produced upon wildlife and water runoff and other physical changes in the natural environment. ${ }^{62}$ Additionally, forest fires caused by a power line failure can be catastrophic. ${ }^{63}$

Another notable problem is the additional air pollution associated with greater transmission distances; if transmission lines carry electricity further from its generation point to its ultimate destination, additional power must be generated due to losses associated with inefficiencies of transmitting power over long distances. ${ }^{64}$ Although it is unclear which power plants this would affect, building more transmission lines shifts the effects of increased air

60. See Federal Energy Regulatory Commission, FERC approves incentives for Pepco's MidAtlantic grid expansion, Nov. 3, 2008, http://www.ferc.gov/news/news-releases/2008/2008-4/11-03-08.asp (last visited Mar. 12, 2010); see also Transmission and Distribution World, Allegheny Energy's Transmission Expansion Plan Receives PJM Approval, July 8, 2006, available at http://tdworld.com/ projects_in_progress/announcements/transmission-expansion-plan/index.html; see also Federal Energy Regulatory Commission, FERC conditionally grants incentives for New York Transmission Line, Sept. 18, 2008, http://www.ferc.gov/news/news-releases/2008/2008-3/09-18-08-E-31.asp (last visited Mar. 12, 2010).

61. Federal Energy Regulatory Commission, supra note 60.

62. See Brian P. Gallagher, Comments on Mid-Atlantic Area National Corridor by Western Pennsylvania Conservancy, July 6, 2007, http://www.nietc.anl.gov/involve/draftcomment/EastCorridor/ act_displayfile.cfm?filename $=81244 \mathrm{c}$.pdf.

63. See Joe Mozingo, Downed Power Lines: A Fiery Culprit Only Money Can Stop, L.A. Times, Nov. 4, 2007, available at http://www.latimes.com/news/local/la-me-power4nov04,0,4195479.story.

64. International Electrotechnical Commission, Efficient Electrical Energy Transmission and Distribution: Electrical Losses and Overall Efficiency, http://www.iec.ch/news_centre/onlinepubs/efficient _transmission/\#section1 (last visited Mar. 12, 2010). 
pollution. This is due to the increased electricity demand seen at the location where the generation takes place. ${ }^{65}$

\section{b. Land-use Drawbacks}

The construction of new power lines also implicates the specific interests that landowners may have relating to where transmission lines are sited. While eminent domain should provide a landowner with a fair market value for land that is taken, the land valuation does not end there. Private property values will generally decrease when transmission lines are built on or near such property because of fears relating to possible adverse health effects from living within proximity to the power lines ${ }^{66}$ even though such health effects have not been conclusively shown. ${ }^{67}$ Whether landowners would be reimbursed for this loss in value is not clear; landowners may have to bring suit if they wish to recover this amount.

Beyond the interests of individual landowners, preservation societies have also protested current plans for power lines in the NIETCs because they are designed to run through areas that have been designated as historic sites, specifically civil war battlefields. ${ }^{68}$ The National Parks Conservation Association has raised the issue that power lines would hurt the ecology and scenery of many national parks, which in turn could hurt the tourism economy and the legacy of the parks for future generations. ${ }^{69}$

65. Vance Little, Using the Commerce Clause to Short-Circuit States' Ability to Pass Power Costs Onto Neighbors, 2008 U. ILL. J.L. TeCH. \& Pol'y 149, 171 (2008).

66. See Sharlene A. McEvoy, Double-Edged Sword of Damocles: Utility Companies' Liability for Diminution of Property Values Due to Electromagnetic Fields, 23 ReAL Est. L.J. 109, 109-10 (1994).

67. See Robert F. Manfredo, Public Use \& Public Benefit: The Battle for Upstate New York, 71 ALB. L. Rev. 673, 690-92 (2008).

68. See Gallagher, supra note 62.

69. See Craig Obay, National Parks Conservation Association, Re: "To Conduct Oversight on the State of the Nation's Transmission Grid, as well as the Implementation of the 2005 Energy Policy Act Transmission Provisions, Including Reliability, Siting and Infrastructure Investment," http:// www.npca.org/media_center/testimonies/energycorridors_073108.html?log-event=sp2f-viewitem\&nid=37326988 (last visited Mar. 12, 2010). 


\section{B. Fuel Sources for Generation}

\section{Fossil Fuels}

Most of the electricity travelling the thousands of miles along power lines making up the grid is generated using fossil fuels. ${ }^{70}$ Current sentiment against the use of fossil fuels because of climate change issues has been reinforced by a recent report from the Intergovernmental Panel on Climate Change ("IPCC"). The Fourth Assessment Report of the IPCC attributes rises in carbon dioxide and other Greenhouse Gas Emissions ("GHG") primarily to the combustion of fossil fuels. ${ }^{71}$ While the federal government has yet to pass legislation regulating GHGs, many states have passed some form of regulation and there is a belief the federal government will do the same in the near future. $^{72}$ This belief is also supported by the U.S. Supreme Court's holding that, by statute, the Environmental Protection Agency ("EPA") can and must regulate $\mathrm{GHGs}^{73}$

\section{Renewables}

As the latest data on electricity generation shows, in 2008 renewable sources made up little more than nine percent of the total electricity generation in the United States. ${ }^{74}$ However, the increasing concern regarding the negative environmental impact associated with the use of fossil fuels has prompted the push for the use of more renewable sources such as wind, solar, geothermal and other sources for electricity generation. But the renewable sources share a common element with the nonrenewable ones: the electric transmission grid will need to develop in order to allow the electricity generated by these sources to flow to customers.

70. In 2008 almost $50 \%$ of electricity was generated using coal. Energy Information Administration, Electricity Explained-Electricity in the United States http://tonto.eia.doe.gov/energyexplained/ index.cfm?page=electricity_in_the_united_states (last visited Mar. 12,2010). Natural gas was the next most common generating source. Id.

71. See Intergovernmental Panel on Climate Change, Climate Change 2007: The Physical Science Basis, Contribution of Working Group I to the Fourth Assessment Report of the Intergovernmental Panel on Climate Change (2007), http://www.ipcc.ch/publications_and_data/ar4/wg1/en/contents.html

72. Kevin Haroff \& Jacqueline Hartis, Climate Change and the Courts: Litigating the Causes and Consequences of Global Warming, 22 NAt. Resources \& ENV'T 50, 50 (2008).

73. Massachusetts v. EPA, 549 U.S. 497, 528-29, 534 (2007).

74. Energy Information Administration, supra note 70. 
Renewable sources also possess other limitations. In some cases, the technology is not available to properly harness the capabilities of the source. This is apparent with current solar technology. In its most commercially viable form, and solar technology has a maximum efficiency of around twenty percent. ${ }^{75}$ These technologies are also at the more expensive end of the range. ${ }^{76}$ More affordable alternatives are being developed, but they offer lower efficiencies, in the range of four to seven percent. ${ }^{77}$ Additionally most renewables are intermittent sources, and the lack of effective storage capabilities further diminishes their effectiveness. ${ }^{78}$ All current renewable sources require a large land area in an advantageous location. ${ }^{79} \mathrm{~A}$ closer look at wind, currently the most popular renewable generation source, provides an example of the advantages and limitations associated with all renewable sources.

\section{a. Advantages of Electricity Generated by Wind}

Electricity is generated from wind by means of a turbine. ${ }^{80}$ Because of the nature of the process, GHGs are not produced at any point, except possibly in the manufacture or construction of the wind turbine. ${ }^{81}$ The American Wind Energy Association ("AWEA") estimates that wind power reduced the amount of carbon dioxide emissions by 28 million tons in 2007 and that each Megawatthour ("MWh") of wind energy can reduce those emissions by 1,200 pounds. ${ }^{82}$ The cost of electricity generated using wind power has also been reduced from a price of around forty cents per Kilowatthour ("kWh") in the 1940 s to around four to six cents today. ${ }^{83}$ Wind as an energy source is growing

75. See Peter Fairley, Solar-Cell Squabble, IEEE SpeCtrum, April 2008, available at $\mathrm{http} / /$ spectrum.ieee.org/energy/renewables/solarcell-squabble/1. Solar efficiency is measured as the percentage of the amount of light absorbed that is converted to electricity. Id.

76. $I d$.

77. $I d$.

78. Fred Krupp \& Miriam Horn, Earth: The Sequel 16 (2008).

79. See generally Robert L. Bradley Jr., The Cato Institute, Renewable Energy: Not CHEAP, Not “GreEN" (1997), http://www.cato.org/pubs/pas/pa-280.html.

80. Ronald H. Rosenburg, Making Renewable Energy a Reality-Finding Ways to Site Wind Power Facilities, 32 WM. \& MARY EnVtL. L. \& Pol'y Rev. 635, 649 (2008).

81. American Wind Energy Association, Resources, Wind Energy and the Environment, Will using more wind energy help to prevent global warming?, http://www.awea.org/faq/wwt_environment.html (last visited Apr. 4, 2010).

82. American Wind Energy Association, 20\% Wind Energy by 2030: Wind, Backup Power, AND EMIssions 1, http://www.awea.org/pubs/factsheets/Backup_Power.pdf.

83. American Council on Renewable Energy, The Outlook on Renewable Energy in America, The Outlook for Technology Innovation to Advance Renewable Energy 12 (2007), 
rapidly in the United States and the AWEA estimates that there are adequate supplies of wind across the country to supply about twenty percent of the nation's electricity demand by $2030 .{ }^{84}$

\section{b. Disadvantages of Wind Power}

While these statistics seem promising, they do not address many of the drawbacks of wind power. One of the problems with wind power is its sporadic nature. Wind power can only generate electricity at certain times of the day, which may or may not line up with demand peaks for electricity. ${ }^{85}$ The loss of generation from wind can lead to blackouts or reduced service capabilities in those areas that rely on wind power. ${ }^{86}$ Climate change can also affect the intermittency of wind, possibly making an investment in a certain area worthless in a matter of years.

Additionally, wind power requires backup from a reserve power source in order to fill in for the times the wind is not adequate. While there are studies to suggest that this reserve is no greater than what is required of current energy sources, ${ }^{87}$ these studies represent the use of wind power at current levels. In 2008, wind power accounted for about one percent of the total electricity generated in the United States. ${ }^{88}$ The issues with the unpredictable nature of wind increase as it supplies a larger percentage of electricity; at some point a utility relying on wind power would likely require backup. ${ }^{89}$ There are also many smaller sub-issues with wind power, including the effects it has on migratory bird species, the large land area that is required, and the visual impact that wind turbines have on the environment.

Despite these issues, what appears to be the largest problem with wind power is the same as that of the transmission grid as whole: the lack of

\footnotetext{
www.acore.org/files/RECAP/docs/OutlookonRenewableEnergy2007.pdf.

84. American Wind Energy Association, supra note 82.

85. Ronald H. Rosenburg, Diversifying America's Energy Future: The Future of Renewable Wind Power, 26 VA. EnVtL. L.J. 505, 526 (2008).

86. See Eileen O'Grady, Loss of Wind Causes Texas Power Grid Emergency, Reuters, Feb. 27, 2008, http://www.reuters.com/article/domesticNews/idUSN2749http://www.reuters.com/article/ domesticNews/idUSN2749522920080228.

87. Michael Goggin, Addressing the Variability Factor: Can Wind Power Reliably Be Part of the Electricity Mix?, Oct. 8, 2008, RenewableEnergyWorld.com, http://www.renewableenergyworld.com/ rea/news/story?id=53784.

88. Energy Information Administration, supra note 70.

89. Energy Information Administration, Renewable Energy Annual 1995, at 90 (1995), tonto.eia.doe.gov/ftproot/renewables/060395.pdf.
} 
sufficient transmission lines. ${ }^{90}$ The DOE estimates that good wind areas make up only a small portion of the contiguous United States land area, with the greatest capabilities located along the coastlines and in the Midwest. ${ }^{91}$ Because many of these sites are in remote locations, they would require long transmission lines to be built in order to connect the generation to the grid. ${ }^{92}$ Further, wind generation sites that are already built have run into problems with congestion in the transmission grid. ${ }^{93}$

\section{DSM as a First Approach to Meet Demand}

DSM is considered by many to be the most practical solution to electricity demand for the near future. ${ }^{94}$ DSM is the term used to describe efforts by utilities to encourage energy efficiency improvements for consumers. ${ }^{95}$ One way this can be done is for a utility to encourage, typically through a rebate or discount program, ${ }^{96}$ small reductions in a consumer's home electric usage by replacing old appliances. Larger applications are also possible, by reducing motor loads in manufacturing industries for example.

DSM originated in the energy crisis of the 1970s and early 1980s. ${ }^{97}$ Amidst the oil crisis and growing concern over the environmental effects of electricity generation, ${ }^{98}$ federal legislation required utilities to conduct energy audits for residential customers. ${ }^{99}$ Due to the regulated markets that utilities operated as that time, prices for electricity were usually fixed over a period of

90. See Nowamoorz, supra note 15; see also Department of Energy, Energy Efficiency and Renewable Energy, Wind and Water Power Program-Technologies-Advantage and Disadvantages of Wind Power, http://www1.eere.energy.gov/windandhydro/wind_ad.html (last visited Mar. 12, 2010).

91. Department of Energy, Energy Efficiency and Renewable Energy, Wind and Water Power Program-Technologies - Wind Energy Resource Potential, http://www1.eere.energy.gov/windandhydro/ wind_potential.html (last visited Mar. 12, 2010).

92. See Rosenburg, supra note 85, at 666 .

93. See Matthew L. Wald, Wind Energy Bumps Into Power Grid's Limits, N.Y. Times, Aug. 28, 2008, http://www.nytimes.com/2008/08/27/business/27grid.html?_r=4\&pagewanted=1\&partner= rssyahoo\&emc $=$ rss\&adxnnlx $=1219849511-\% 20 \mathrm{kDLvyUPVdJs} 8 \mathrm{nmE2pOZgA}$.

94. Omar Siddiqui, Demonstrations Encourage Wider Use of Efficient Technologies, EPRI Journal, Winter 2008, at 15, available at http://mydocs.epri.com/docs/public/000000000001018279.pdf.

95. See Ето, supra note 15.

96. An example of this is the Watt Watchers program provided in Pennsylvania by Allegheny Power. The program gives customers a rebate when they purchase an appliance that meets a prescribed efficiency level. See Allegheny Power, Watt Watchers Programs, http://www.alleghenypower.com/EngConserv/ PA/WattWatchers/ResEECPA.asp (last visited Apr. 4, 2010).

97. See Ето, supra note 15.

98. Id.

99. Id. at 5 . 
years. ${ }^{100}$ Accordingly, many utilities experimented with DSM as a way to reduce costs. ${ }^{101}$ These efficiency expenditures appear to have reached a peak of $\$ 2.9$ billion in the early 1990's as electricity markets began the process of deregulation. ${ }^{102}$

The recent rise in electricity demand and electricity prices, increasing competition for fuel sources of traditional generation, and concerns over the security of energy have all led to a resurgence of DSM programs. ${ }^{103}$ While renewable energy has made advances in the reduction of GHG emissions, so have DSM programs. Recent data shows that DSM programs were responsible for alleviating thirteen percent, or about 34 million tons, of carbon based GHG emissions in 2005. ${ }^{104}$ Additionally, a recent study by the Electric Power Research Institute ("EPRI") ${ }^{105}$ shows that DSM programs that utilize currently commercially available technology can cut the expected increase in peak electricity demand between $14 \%$ and $20 \%$, if not more, within the time frame of 2008 to $2030 .^{106}$

\section{A. DSM More Closely}

DSM solutions are typically broken down into three categories: end-use efficiency, load management, and fuel-substitution. ${ }^{107}$

\section{End-use Efficiency}

Conservation activities have also been called end-use efficiency to avoid confusion with the term energy conservation. End-use efficiency "means doing more (and often better) with less," whereas energy conservation means

100. Id.

101. Id. at 6 .

102. Id.

103. See generally Edward H. Comer, Transforming the Role of Energy Efficiency, 23 NAT. RESOURCES \& ENV'T 34 (2008).

104. Id. at 34 .

105. "The Electric Power Research Institute (EPRI) is an independent, non-profit company performing research, development and demonstration in the electricity sector for the benefit of the public." Electric Power Research Institute, Who We Are, http://my.epri.com/portal/server.pt? (last visited Apr. 14, 2010).

106. Electric Power Research Institute, Assessment of Achievable Potential from Energy Efficiency and Demand Response Programs in the U.S. 7, 8 (2009), mydocs.epri.com/docs/public/ 000000000001018363.pdf.

107. See Bertschi, supra note 16 , at 840 . 
"simply doing less or worse or without." ${ }^{108}$ Conservation programs are the most common forms of end-use efficiency and include incentives for green building techniques, efficient appliances, and maximizing efficiency of industrial processes ${ }^{109}$ Pricing strategies for electricity can also be a method of increasing end-use efficiency. If electricity rates are fashioned in a block form where, like the structure of income tax, consumers would pay more for certain levels of usage, they would be more likely to see the benefits of using electricity efficiently. ${ }^{110}$ Despite the advances in technology, one of the most cost-effective ways for utilities to increase end-use efficiency is simply by supplying information to consumers on energy use. ${ }^{11}$

\section{Load Management}

Load management, also called demand response, describes the process to provide such information. Demand response does not have to do so much with reducing the amount of electricity used but rather with reducing the use of electricity at the time of peak demand. ${ }^{112}$ Utilities usually size equipment to be sufficient during peak demand situations; therefore, reducing peak demand can reduce the need for new generation facilities. ${ }^{113}$ However, the cost savings relate not just to capital investments such as new facilities, but also to electricity that a utility may have to purchase on the wholesale market. Because costs for electricity follow a typical supply and demand curve, when electricity demands are highest, so are costs.

Demand response solutions typically include peak-load pricing and interruptible service. ${ }^{114}$ With interruptible service, customers voluntarily contract with a utility to allow their service to be interrupted under certain conditions, typically when the utility is experiencing peak load, in exchange for some form of compensation. ${ }^{115}$

Peak-load pricing relates to the supply and demand of the wholesale electricity market. If consumers are subjected to this kind of pricing, economic

108. ARMORY B. LOvins, ENERGY END-USE EFFICIENCY 2 (2005), available at http://www.rmi.org/ $\mathrm{cms} /$ Download.aspx $?$ id=1389\&file=Energy+End-Use+Efficiency.pdf.

109. See Bertschi, supra note 16 , at 840 .

110. Id. at 841

111. $I d$.

112. $I d$.

113. Id. at 842

114. $I d$.

115. Bertschi, supra note 16 , at 842 . 
factors lead them to reduce usage when the price is highest. ${ }^{116} \mathrm{~A}$ smart meter is a recent innovation that can augment the effectiveness of peak-load pricing by telling a consumer when peak load conditions are taking place and allow the consumer to act accordingly. ${ }^{117}$ The technology of these meters can vary. In some cases, the meters can be connected to a network in a consumer's home or business and allow communication between the utility and consumer, or even allow the consumer or utility to control the electricity demand at the site remotely. ${ }^{118}$

\section{Fuel Substitution}

Fuel substitution programs involve using the most cost-effective energy source for a given task. ${ }^{119}$ This can include switching from an electric appliance to a gas appliance such as a water heater, depending on which is more suitable for the particular application. ${ }^{120}$ The use of renewable energy sources, such as the use of on-site solar panels, is sometimes combined under this category. ${ }^{121}$

\section{B. Barriers to DSM Implementation}

Knowledge, costs, and regulatory policies have significantly hampered the implementation of DSM plans. Knowledge barriers exist in many cases because consumers do not know about DSM initiatives or the amount of savings that they can provide. ${ }^{122}$ Additionally, if the decision to invest in energy efficiency lies with a homebuilder or developer, the incentive of cost savings on utilities bills can be ineffective if the builder or developer will never see the savings. ${ }^{123}$ Despite this, some builders and home developers have resorted to providing buildings that meet energy efficient standards and have

116. See Gene Wolf, It's So Much More Than a Smart Meter, Transmission and Distribution WORLD, Apr. 1, 2008, available at http://tdworld.com/customer_service/much_more_smart_meter/.

117. Id.

118. $I d$.

119. See Bertschi, supra note 16 , at 843 .

120. $I d$.

121. See generally Daniel L. Greenberg et al., Environmental Protection Agency, Demonstration of the Environmental and Demand-side Management Benefits of GridConnected Photovoltaic Power Systems-1994-1997 (1998), http://www.epa.gov/cgi$\mathrm{bin} /$ epalink $? \operatorname{logname}=$ allsearch \&referrer $=$ demand $\% 20$ side $\% 20$ management $|2|$ nepis \&target $=$ http://nepis.epa.gov/Exe/ZyPURL.cgi?Dockey=P1000IA5.txt.

122. See Comer, supra note 103, at 34 .

123. Id. 
attempted to sell this buildings at a premium based on energy savings. ${ }^{124}$ What has followed, however, is a market that does not value the green improvements according to the costs of installation but rather values the improvements based on what banks are willing to loan to customers. ${ }^{125}$ The result is that homebuyers have difficulty receiving financing for green buildings, and builders and developers have difficulty selling these improvements. ${ }^{126}$

Beyond this, the upfront cost of efficiency investments is likely to stop many consumers. Individuals and businesses are not likely to make the large expenditures needed without a good understanding of how the cost of electricity can be affected by energy savings. ${ }^{127}$ The fact that many consumers pay for electricity based on an average for the day, and not on a time-of-day scale like utilities, discourages these expenditures. ${ }^{128}$

Costs can also discourage utilities from making investments in this area. As most technological investments require significant capital, utilities may not see a return on that investment unless there is a built-in recovery procedure. ${ }^{129}$ To encourage investment in energy efficiency on the part of utility companies, some states that have adopted Renewable Portfolio Standards ${ }^{130}$ ("RPS"), which require the implementation of DSM programs and provide incentives for utilities to invest in these programs. ${ }^{131}$ However, in some cases, funding for DSM programs may be lacking because of the current political focus on renewable energy sources. ${ }^{132}$

Even with RPS mandates, utilities still make the majority of their profits from consumers' use of electricity. Therefore one of the main concerns of regulation is that utilities traditionally earn money based on a "cost of service"

124. See Les Christie, Green homes face a red light, CNN, Mar. 10, 2010, http://money.cnn.com/ 2010/03/10/real_estate/green_homes_redlight/.

125. $I d$.

126. $I d$.

127. See Comer, supra note 103 , at 34.

128. Id.

129. Id. at 36 .

130. An RPS places a requirement on the entities that sell retail electricity to ensure that a certain percentage of electricity generated comes from renewable resources. See Nathan E. Endrud, State Renewable Portfolio Standards: Their Continued Validity and Relevance in Light of the Dormant Commerce, the Supremacy Clause, and Possible Federal Legislation, 45 HARv. J. on LegIs. 259, 262-63 (2008).

131. Barry Rabe, Race to the Top: The Expanding Role of U.S. State Renewable Portfolio Standards, 7 Sustainable Dev. L. \& Pol'y 10 (2007). For examples of possible incentive approaches, see Comer, supra note 103 , at $36-38$.

132. See generally American Wind Energy Association, Wind Industry Eyes Record Year of Job Growth, Job Creating, http://www.awea.org/news/news050426qmk.html (last visited Jan. 15, 2009). 
approach. ${ }^{133}$ Cost of service means utilities are allowed to recover their expenditures for infrastructure investments in addition to a reasonable rate of return on the sale of electricity. ${ }^{134}$ This regulatory system allows utilities to be rewarded for selling more electricity. ${ }^{135}$ Such a system can be in direct opposition to the implementation of DSM programs. Therefore, it is generally agreed that in order for a DSM program to succeed a utility's revenues must be decoupled or detached from the sale of electricity. ${ }^{136}$ This can be done by making rate adjustments based on utility's expenditures for a DSM program or providing incentives for meeting efficiency targets. ${ }^{137}$ Various states have tried this with differing degrees of success. ${ }^{138}$

\section{The Federal Government's Role in Implementing DSM}

The Tenth Amendment generally limits the amount of control a government agency, such as FERC, can exert over a state. ${ }^{139}$ In the case of New York v. United States, ${ }^{140}$ the U.S. Supreme Court held that the Tenth Amendment might block Congress from exercising its power under the Commerce Clause when it comes to regulating state activities:

We have always understood that even where Congress has the authority under the Constitution to pass laws requiring or prohibiting certain acts, it lacks the power directly to compel the States to require or prohibit those acts. The allocation of power contained in the Commerce Clause, for example, authorizes Congress to regulate interstate commerce directly; it does not authorize Congress to regulate state governments' regulation of interstate commerce. ${ }^{141}$

Even though wholesale electricity transactions that involve transmission lines are typically seen as involving interstate commerce, ${ }^{142}$ FERC's

133. Irma S. Russell \& Jeffery S. Dennis, State and Local Governments Address the Twin Challenges of Climate Change and Energy Alternatives, 23-SUM NAT. ResourCES \& ENV'T 9 (2008).

134. Id.

135. Id.

136. See Comer, supra note 103, at 36; see also Bertschi, supra note 16, at 845 .

137. Edan Rotenberg, Energy Efficiency in Regulated and Deregulated Markets, 24 UCLA J. ENVTL. L. \& POL'y 259, 288-89 (2006).

138. See Bertschi, supra note 16 , at 844-47.

139. U.S. ConsT. amend. X ("The powers not delegated to the United States by the Constitution, nor prohibited by it to the States, are reserved to the States respectively, or to the people.").

140. New York v. United States, 505 U.S. 144 (1992).

141. Id. at 166; see also Jared O'Connor, National League of Cities Rising: How the Telecommunications Act of 1996 Could Expand Tenth Amendment Jurisprudence, 30 B.C. EnvTL. AfF. L. REV. 315, 334 (2003).

142. Laura Duos, Order 888: Has the Federal Energy Regulatory Commission Invaded the States' 
regulatory power over state public utility commissions is limited. ${ }^{143}$ FERC's authority to implement DSM programs would likely be limited to the provision of information about the benefits of such programs or to adjust transmission rates to favor those utilities that provide such programs. ${ }^{144}$

Congress's power to pass legislate regarding GHG emissions provides another avenue for the federal government to achieve nationwide implementation of DSM programs. Many proponents of GHG regulation believe that Congress should pass a law giving utilities financial incentives to reduce GHG emissions. ${ }^{145}$ One popular plan is a cap and trade system, under which a limit would be set on the total amount of GHG emission allowable for utilities; the utilities that come in under the allowable cap would receive credits, which they could sell or trade to other utilities that could not meet the cap. ${ }^{146}$ A carbon tax is another popular, not to mention simpler, alternative. These programs work by placing higher taxes on energy sources that are high in carbon, such as fossil fuels, because of the significant GHG emissions associated with these sources. ${ }^{147}$ As the application of the tax causes the price of high-carbon sources to rise, energy savings programs and lower-carbon or no-carbon electricity generation sources become more cost-effective. ${ }^{148}$ While the relative likelihood of success between the two programs continues to be debated, ${ }^{149}$ either would likely serve as an incentive for DSM programs. ${ }^{150}$

Another option that has received less attention is the idea of tax incentives alone that would encourage DSM programs. For example by providing a tax refund for consumers or utilities based on every $\mathrm{kWh}$ of electricity saved. This approach could be employed either independently or in tandem with one of the programs discussed previously.

Jurisdictional Territory?, 54 Admin. L. Rev. 1213, 1216 (2002).

143. See Duos, supra note 142, at 1213, 1215-16.

144. See id. at 1218 .

145. Scott H. Segal, Be Cool! Staying Open Minded About Climate Policy Development, 18 DuKE ENVTL. L. \& POL'Y F. 307, 312-14 (2008).

146. $I d$. at 312 .

147. $I d$. at 313

148. Id.

149. Id. at 314 .

150. Similarly, EPA regulations that limit emissions of GHGs would also provide incentives for DSM programs to help utilities and power plants meet goals under such regulation. There is a growing belief that the EPA will pass GHG regulation in the face of the lack of Congressional action on the issue. See John M. Broder, E.P.A. Moves to Curtail Greenhouse Gas Emissions, N.Y. Times, Oct. 1, 2009, at A1, available at http://www.nytimes.com/2009/10/01/science/earth/01epa.html?_r=1\&hp. 


\section{CONCLUSION}

The blackout of August 2003 demonstrated that current technology is insufficient to address the complexity inherent in operating the electric transmission grid. This event raised the consciousness of many people who took for granted one of man's greatest discoveries: electricity. Because of the recent challenges of high energy prices, environmental concerns, and energy security, policymakers and citizens have begun to focus on electricity infrastructure investment and using dedicated renewable energy sources as solutions to these challenges. The basic problem with these two paths is that they deal with increasing demands by increasing the use of resources. By relying on DSM, however, the demands of the electricity markets will be met by using fewer resources more effectively.

The potential success of a the DSM program is best exemplified by California's solution to its energy crisis at the turn of the century. In 2001, California was in the midst of rolling blackouts and energy shortages, which lead then governor Gray Davis to declare a state of emergency. ${ }^{151}$ In response to the situation, the State called on the influential parties, the utilities, consumer groups, corporations, the legislature, and the utility commission-in order to find a solution. ${ }^{152}$ The state came up with a plan to use $\$ 1$ billion to invest in DSM activities and was able to conserve approximately 5,000 MWh of electricity, which effectively averted the crisis. ${ }^{153}$ Since that time California has approved efficiency programs that have lead to a fifteen percent yearly reduction in electricity consumption. ${ }^{154}$ While the rest of the United States per capita electricity consumption has increased over the years, California's has remained relatively flat since $1975 .{ }^{155}$

As California's example shows, DSM can meet the demands of future electricity markets. However, the approach to applying a DSM program must be uniform because the transmission grid acts as a connected web distributed among the many states. Accordingly, differing state regulations, financial restrictions, and the variety of interested parties could pose a problem to a unified approach. Therefore, to ensure that future electricity demand is met

151. Craig Canine, California Illuminates the World, National Resources Defense Council: OnEARTh, Spring 2006, http://www.nrdc.org/onearth/06spr/cal asp (last visited Apr. 4, 2010).

152. $I d$.

153. $I d$.

154. $I d$.

155. Brent Barker \& Lucy Sanna, Turning on Energy Efficiency, EPRI J., Summer 2006, at 11, available at http://mydocs.epri.com/docs/public/000000000001013720.pdf. 
properly the federal government must adopt a uniform national policy that places DSM as a priority. 
